Témoigner

Getuigen
Témoigner. Entre histoire et mémoire

Revue pluridisciplinaire de la Fondation Auschwitz

$118 \mid 2014$

Au nom des victimes. Dictature et terreur d'État en Argentine, Chili et Uruguay

\title{
The Great War: from witnesses to historians, from memory to history?
}

La Grande Guerre: du témoin à l'historien, de la mémoire à l'histoire?

De Grote Oorlog: van getuigen naar historici, van herinnering naar geschiedenis?

\section{Nicolas Beaupré}

\section{Q OpenEdition}

Journals

\section{Electronic version}

URL: http://journals.openedition.org/temoigner/1095

DOI: 10.4000/temoigner.1095

ISSN: 2506-6390

\section{Publisher:}

Éditions du Centre d'études et de documentation Mémoire d'Auschwitz, Éditions Kimé

\section{Printed version}

Date of publication: 1 October 2014

Number of pages: $48-54$

ISBN: 978-2-84174-674-3

ISSN: 2031-4183

\section{Electronic reference}

Nicolas Beaupré, «The Great War: from witnesses to historians, from memory to history? », Témoigner. Entre histoire et mémoire [Online], 118 | 2014, Online since 01 October 2015, connection on 23 October 2020. URL : http://journals.openedition.org/temoigner/1095 ; DOI : https://doi.org/10.4000/ temoigner.1095 


\section{The Great War : from witnesses to historians, from memory to history?}

$\mathrm{T}$

opposition between esses and historian as figures, narrators an a and reflecting in pat the past

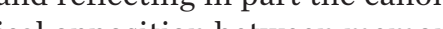
and history is commen menory an In the crystallzation of these two Creat War plays a oule thet (a) With the deth in 2008 of Lance. Ponticelli, the "last remaze ponticelli, the "last remaining poilu", and at a time when there live in the wonten whe First World War as children, the

(1) Beaupré, Nicolas, Christian Ingrao \&
Annne Dumenil, Des Guerres $1914-1918$ et
Ans

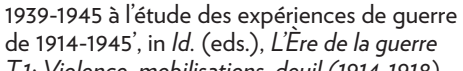
T.1: Violence, mobilisations, deuil (1914-1918)

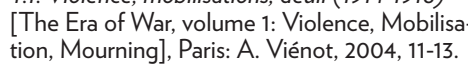
(2) Offenstadt, Nicolas, 14-18 aujourd'hui. La
Grande Guerre dans la France contemporaine Grande Guerre dans la France contemporaine
[The First World War today. The Great War
incontemporary France.] Paris: Odile Jacol 2010.

(3) For a clarification on these debates see namely Beaupré, Nicolas, Les Grandes Guerres
$1914-1945$ The Great Wars 1914-1945], Paris:
Belin, 2012, 1046-1050 (4) Rousso, Henry, 'Preface', in Nicolas Beauprer
Les Grandes Guerres 1914-1945, op. cit., 7. (5) Prost, Antoine \& Jay Winter, Penser la flections on the Great War. A historiographica era of witnesses of the Great War seems definitely to have given room ens etween the deth rom onwards of the last generation havinglived the last gentathe havinglived the Great War and the haing mainlyon thecriticisnoftestinonial voices, seems at first glance to

We can observe, indeed, since roughly twenty years, a very keen nd a significant increase in the tudy of historiography along wit (onsent, the culture of war, soldier testimonies) of which we can wonder if they dontowe then to the renewed interest in thesos con to nevertheless follow Henry Rousso with the following reny Rousso with the following remark as he compares the links between the conflicts:

Whereas the controversies surrounding the memories of the Occupation and, more precisely, the involvement of the French state in the genocide or the Jews, the field of historiography ticld of historiography was experiencing a form of consenus. The authors favourable to the its results a it was the desond the 1960s and 1970s, proved to be more and more rare because of the lack of solid arguments. Conversely the polemic that recon raged among (French) historians to determine whe tetrences ad cepted unusual rees riolencebyconsentorby force, has mely ha a wo coree, has merely had a weak echo in the public and political sphere. People, as it seems, are mobilized this by the con, aru vivors a courd

Now with full attention on the commemorations of the centenary, theinteresthas neverent. There is undeniably a very keen The che memory of the Gretwa The ring minfigures of this memory are the it the at ing, were bothactors and narrators of heir experience providing a key contribution to the elaboration of agreat menorialnarive. In this perspective, it seemsinteresting to of the occasion of the occasionally tumultuous relation between historians and witnesses, between history and As Antoine Prostand Ja W

As cthe Par in 1914 doy Winte belong "the war in 1914 does not berions" 5 In fact since it begun we have not ceased tilling we have not ceased telling and explaining the Great War, exercises a minor an confronted by other were early on confronted by other writings of the Great War and, namely, to the voice ofwitnesseswhovery quickly,

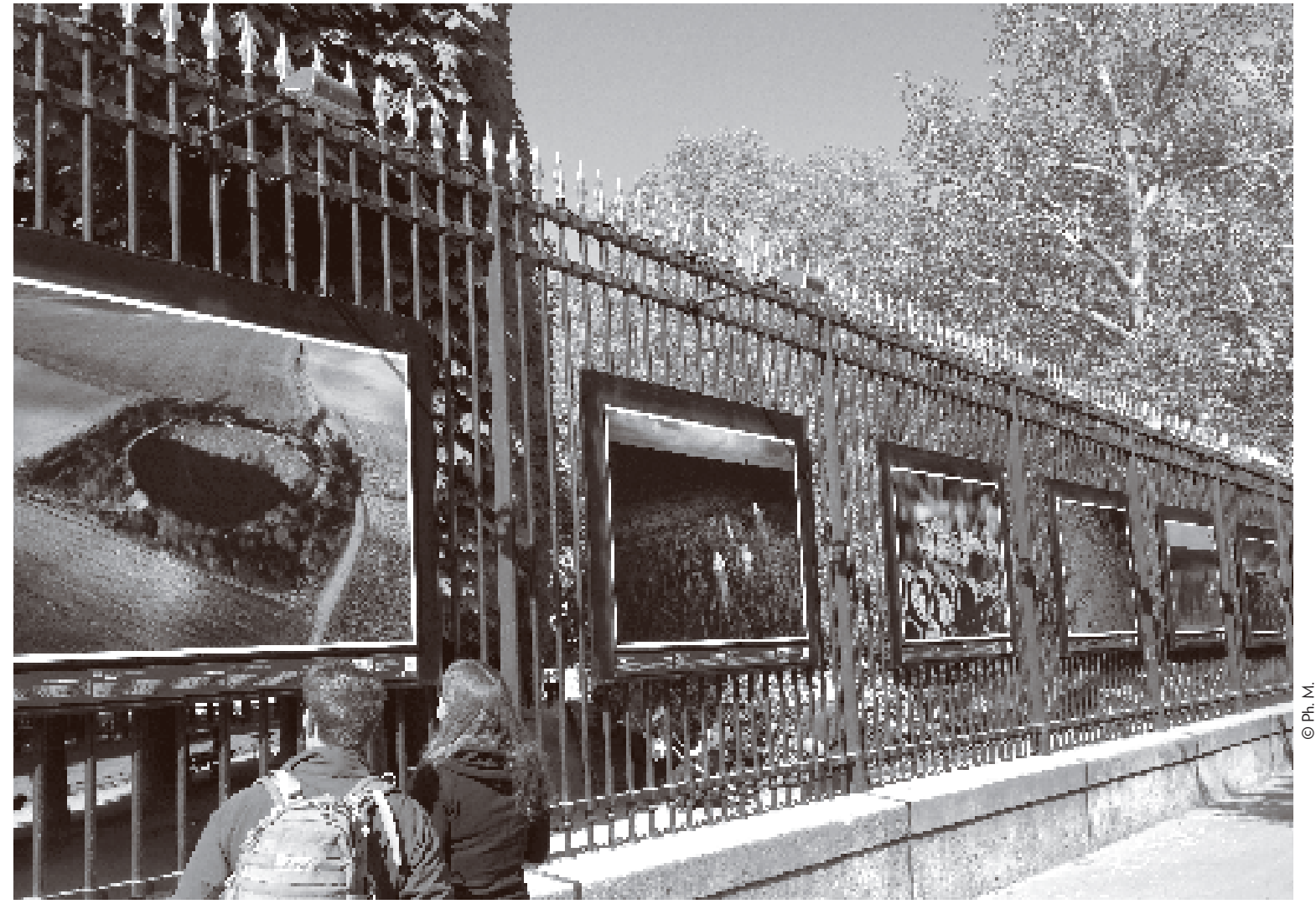

ered just as legitimate to talk of the war. From then, the relation that historians maintained with this kind of expression was for a long time anbivalent, or of a competitive naturestill, it cannot be

\section{THE EMERGENCE OF}

TESTIMONIES AS A SOURCE.

If we follow Jay Winter and Antoine Prost, ${ }^{6}$ the historiography of the Great War articulates itself writing periods closely remain to their peritical closely related their political uses and to the conteries. Within these historiographic, as well as memory configurations, the place of ry configurations, the place of have evolved.

The first configuration, starting during the war and confirm immediately after 1918, would ssentiallybepolitical and military. essentiallybepoiticaland willtary. Its goal was to study the causes of such or war-was war - waseitherlostorwon. Allthat tionalitics the Germany) article 23 (especially in of Versaill s reso less than a historical analysis of
-All photographs in this article are Battle / Terres de Paix $14-18$, on display rom 4 April to 4 August 2014 on the uxembourg and directly in front of the Palais du Luxembourg. Photographer: Michael St Maur Sheil.

the causes of the conflict. It stiplated indeed that "Germany and its allies are responsible, since they caused them, for every loss and al ments of the allies, associates an eir nationals as a consequence of the war that was forced upon then

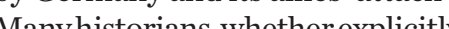

(6) lbid the damage suffered by the govern- 
œ or not, have since then taken a position on this article.

Thegoal wasto study the causes the consequences and the deve opment of the conflict. This was ery that triumph of the so-called positivist or methodical history. In this

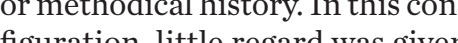
guration, litle regard was given tore mersoldierslikeHenryContamine

(7) In the case of Germany, see Majerus,
Benoit \& N Nicolas Beaupré, 'Ecrire la Grande

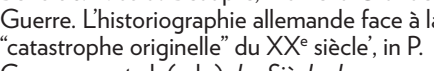
Causarane ot aline (eds.), L L Sieccle des guerres
Penser les guerres du premier XX siècle IA Penser les guerres du premier $X X^{\circ}$ siècle $[A$
century of war. Reflections on the wars of the first half of the

(8) Regarding the case of Pierre Renouvin,
see Audoin-Rouzzau, Stéphane, Combattre Une Anthropologie istorique de la guerre moderne $\left(X I X^{e}-X X^{*} S\right.$ S.) [Combat. A historical
anthropology of modern warfare, Paris: Seuil, 2008, 93-102

(9) Quoted in Penser la Grande Guerre, op.
cit, 27.

(10) Beaupré, Nicolas, 'Du Bulletin des Ecrivains
de 1914 à I'Association des Ecrivains Com-

de 1914 à l'Association des Ecrivains Com-
battants (AEC): des combats à la mémoire.

battants (AEC): des combats à la mémoire,
$1914-1927$ ', in La Politique et la guerre. Pour,
comprendre le X Xe siècle europeen, Hommage
à Jean-Jacques Becker [Politics and war. Under-

à Jean-Jacques Beccker [Ploliticis and war. Under-
standing the $20^{\circ \text { ch }}$ century in Europe. A tribute standing the $22^{\text {th }}$ century in Europe. A tribuer
to Jean-Jacques Becker,. Paris: A. Vienot/
Noôsis 2002 $301-315$ On the polemic see Noêsis, 2002, 301-315. On the polemic see
Rousseau, Fréderic, Le Proceses des témoins la Grande Guerre, Lafffaire Norton Cru [The
witnesses of the Great War on trial. The case of Norton Cru], Paris: Seuil, 2003 and the republishing of Norton Cru's Témoins [Witness-
es] from 1929 (Nancy: Presses universitaires de Nancy, 2006).

(11) lbid.

(12) Becker, Jean-Jacques, 1914 Comment les
Français sont entrés en guerre [How the French went to warl, Parisi: Presses de la Fondation nationale des sciences politiques (FNSP),
1977 ; Prost, Antoine, Les Anciens Combattonts et la société françaiase [The former combatants
and French society], Paris: Presses de la FNSP. and one of the most renowned specialists of French military history or ven Pierre Renouvin, ${ }^{8}$ founder of new approach to internationa elations, distrusted the voice of former soldiers and witnesses. Even though Renouvin lost an arm, wrote in 1939: "The testimonie of soldiers, though very useful t read in order to understand the atmosphere of the battle, can seldom give any information on how perations were conducted, as the horizon of the witnesses was too linited. However, hewar period , toalesserextent, the timethat the pethollowed, was narked "thestimon" in a brotions of At the ent of the broad sense. de the end of the 1920s a lively debate even opposed their most certain number of what was then certain " number of what was then elt a form of disinterest for felt a form of disinterest for these that were fon thong abund, in mes of sollers. As if history had egun wint a divorce rather tha

The second configuratio would seemingly have emerge the end of 1950s and at the was then ris 1960 . The focus wasial actors of the tow firtly social actors of the war, firstly to his period was inded mared by this period was indeed marked by f Marxistinterpretations hifting the attintion towat ans the attention toward actors other than diplomats, politicians and and to Prost this social shift from the field of historiography was the field of historiography was bovi Vieetmort des Francis [Life book. Wiet onot des Frang by Hachette in 1959, co-written by Jacques Meyer, Gabriel Perreux and André Ducasse, three former students of the Ecole Normale who passed the agrégation in hisand who were also former soldiers. The book was only accepted by the publisher because it was prefaced by a fourth former soldier who was better known than This "hydes, Maurice Genevoix. tion of " tion of academic historiography and an anthology of the writersthe way the corflotwo vew the way the conflict was viewed by focusing on society, at the fron and at home, and by providing new questions. The place of witnesses and of testinonies remained no less anbiguous in the works of the attitu, even if the interest in the beging the beginning until after the war the recall here namely the doctora theses of Jean-Jacques Becker and Antoine Prost both published in 19772 progressively contributed in making testinonies recognized as allotherdocuments, destined to beboth subnitted tocritical analysis and also incorporated into hisThe third configur

third configuration that occurred in the late 1980s and beginning 1990s was both socia and cultural. We stillfind ourselves at this period today. It is namely a period founded on a pronounced interest for "representations", the into the linding into the larger history, the practines, the wounds, the the suffering, the wounds, the traumas... A privileged source for this type of history, testimonies and witnesses precisely at a time when they were dying. The two editions of Témoins Witnesses] by Jean Norton Cruin 1993, then in 2006, exemplify this. Moreover, many studies are now specifically dedicated to the voice of soldier testimonies thus becoming not only a source, but also an object of history, a subject for doctoral projects, books and articles.

Nevertheless, our reading could be reversed. Indeed, the centrality of testimonies has led Annette Becker and Stéphane AudoinRouzeau, who have abundantly Rouzeau, who have abundantly call in year 2000 for freedom from is prue that hedeathofwitnesses is paradoxically not characterized of their influence. Un voice nor there is an ince. Until today, there is an increase in all sorts of testinonies and this undoubtedly will not cease with the Centenary. Their publication encourages certain publishing houses to speby writing this, both historians by withing this, both historians were certainly not calling for the source, but rathe to monics as a source, but rather to monses as a rial surge.

\section{OR THE RETURN}

\section{OF WITNESSES}

This is how we could retrace in broad strokes the story of what could be a progressive integration of testimonies within historiographic discourse. According to from the winter, the transition pron thephistorians, fromestothe periodofhistorians, from memory to history, is neither progressive nor linear. Both these writings, ographic, are developed in parallel,

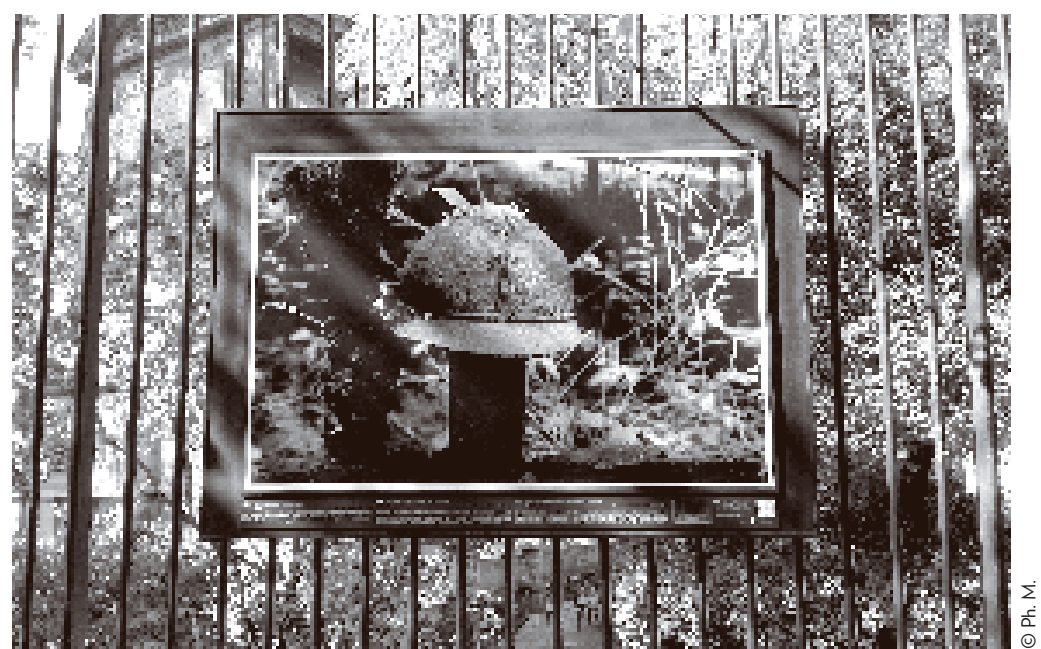

coexist and cross over at times. Thi is the case for Ducasse, Perreux an Meyer or even for Jean Norto Cruwho, however proposed asupCruwho, however, proposedasupered "scientific".

Thus, it is necessary to nuance Winter and Prost's affirmation War me beginning of the Great War marked the beginning of a poltical, diplonatic and military phyand thereby adistongrphy and, thereby, a distancingof the Yet, it now turns out that the lictit now turs out that the puba highly legitimate narrative of the

(13) Audoin-Rourzau, Stéphane \& Annette Gecker, 14-18, Retrouver Ta Guerre, Paris:
Gallimard, 2000, 52. (14-18 Understanding
the Great War, New York: Hill \& Wang, 2002)

(14) In his thesis, Benjamin Gilles did some calculation that demonstrate this. In a published book, he mentions 1,265 French
testimonies published from 1914 to 2011 . See Benjamin Gilles, Lire dans les tranchéés
[Reading in the trenches], Paris: Autrement

(15) Norton Cru, Jean, Du témoignage
[On testimony], Paris: Gallimard, $1930,9$. war and represents a strong voice (immediately listen o. An interest has developed at east as much, if not more, for the aily lives of the soldiers, for the shape modern war takes. Now, the voice of the soldiers, responding legitin we would be mistaken to believe that it is a margina phenomenon A few hundred tesphenomenon. A few hundred tespublished in a broad sense, were A comparbenomen took ploce in the other enenon took pries in the other engaged counhistorians who took partinertain also judged it useful to write the aw judged it useful to write their did. However, Bloch dare Bloch to publish it and following the war he became interested, in article published in 1921 , in the circulation of "false news" during to a historian perspective, whilstbe preciously ahead of its time to an analysis of the social function to an circulation of information during $\bullet$ the war This was a way to return 


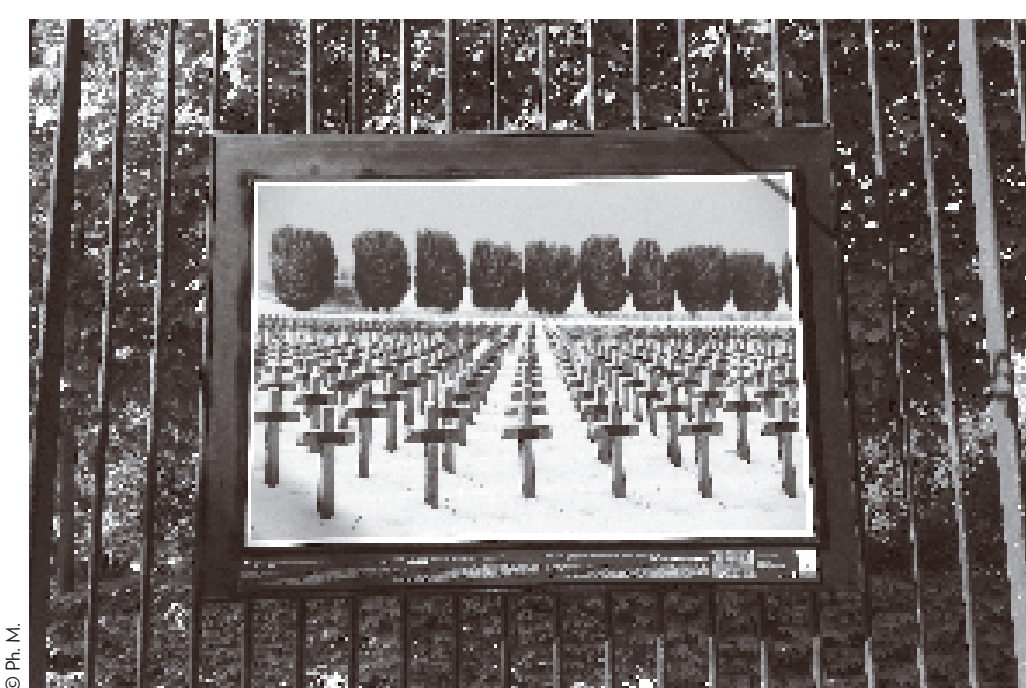

war time ${ }^{16}$ In any case, if historica and testimonial voices seem perectly distinct, histo contrary, have not lost interest in the work of soldier witers. Thus, Ernest Lavisse - believing that historians ought to be engaged in their day - accepted topreface at least three books written by soldiers during the war. Along with the sociologit the publishing house he created at the publishing house Arnand Colin the "Étudesel documents sur la guerre" [Studies an documents on the war collection justice in France. Whereas socis justice in he did not pustin this costimonies strictly speaking his testimonies strictly speaking, his "senre" that was then succestora genre" that was then successful. In the same vein, La Revue historique, though orthodox in its relation to between 1914 and 1918 reviews between 1914 and 1918 reviews of Concerning the imorwar. post-warperiod, disinterestfor wa literature was not specific to histoWe easily notice a decline in he que tity of tetice a decline written at the beginning of the 1920s, at the bining of the . end of the decade. The decline in pation ought to be analyzed in paralle to historical works pertaining to the conlict. This was perhaps due to a broader disinterest than just the beginning at the 1930 s, soldie wegining at the 1930s, soldier writers more readily chose towrte Gis. It thus notsurprising the hexts that had a way fronthese texts that had a more ambiguous status, lyingbetween narrativeand journal, testimony and fiction. If oryjournals either of a testimony much less so the chis was very even if it had a testimonial dimen-

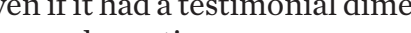

Let's recall now the main outinitiated by Jean Norton Cru. A tory journals, either of a testimony
French, English and American academic and a former soldier, ${ }^{18}$ he proposed in two books, Témoin and Du témoignage, published at the very time when there was a review or more French works gathering testimonies. Thous not a historian nies. Though not a historian by a renownod cubrished in a renowned collection of history foundationforpea the Carnegie received in France How soorly Norton Cru intended this work Norton Cru intended this work for historians, by electing least for historians, by selecting among studied. In order to do so, he used studied. In order to do so, he used the methodology of historians by basing his analysis on the extersources, in which his own subjectivity also wich his own subjectivity also energed. As more than one historian had conrectly suggested, Jean Notoncru, wishing at unable to and Tém es follow, was year later by Du témoignage, ca year later by Du témoignage, can mony. We here have the example

\section{(16) These writings are gathered in the work} by Marc Bloch, Lhistoire, la guerre, la résistance [History, War, Resistance], prefa
Becker, Paris: Gallimard, 2006 .

(17) Prochasson, Christophe, Les Mots pour le dire, Jean Norton Cru, du témoignage à
lhistoire' [Finding the words, Jean Norton Cru, from testimony to history], Revue $d^{\text {histoire }}$ moderne et contemporaine 48, 2001, $161-189$.
See also Penser la Grande Guerre, op. cit., $30-$ 31 , for the period after 19

\section{(18) His war letters were recently published
with a detailed presentation of the author} Norton Cru, Jean, Lettres de guerre et
d'Amérique 1914-1919 [Letters from war dAmerique 1914-1919-[Letters from war and
from America, Aix-en-Provence: Presses de I'Université de Provence, 2007 (19) Norton Cru, Jean, Témoins and Du témoi-
gnage, op. cit. of a hybrid work that is neither history nor testimony and yet that is both at the same time. Additionally, if the scandal provoked by Jean Norton Cru's reception in literary circles is well known, the reception of his work by historian is much less so. We already notice hat historians did not remain distanced from the reception of Jean Norton Cru's work even if it wer essentially men of letters who reacted. In the resource supplement published in the second edtion of Temoins in 2006, we note that some historians, and weluding Jules Isac), (Patice Renouvin, Jules Isaac), participated in it, as did formér soldiers who passed the agrégation in history (A
Ducasse, Charles Delvert). ${ }^{20}$

In a certain way, beyond Prost In a certain way, beyond Prost and Winter's reviews on the meekness and the absence of the war experience in the academic historivery little on how war lite know very little on how war literature historical journals and by histohistorical journals and by histo1914-1918 and after 1918, the voic of soldiers and testim, the voice sor the opposite the opposite.

After the Second World War however, things seemed to operof historians came che experience of soldiers, no experience of soldiers, namely frit the 1960s, the direct voice of witnesses strugged tobeheard and the publication of testimonies and of war narratives about 1914-1918 of Vie et mort des Franc of Vie et mort des Français (1959) shows all the potential interest in a historical source, but the three
The memory of the Second World War, its presence today and the debates that surround the event, surely contribute to a certain fading of the memorial figure of "moral witness" of the Great War.

uthors intervened more in the field as historians and as popu. Whereas they had, before 1939 purlesers dailylife the frontang a daily life at the front and another as history books ${ }^{21}$ Even manted as history books. Genevolx who wrote the preface, found the Mun and the discourse of dun. Benefiting from his fame, dun. Benefiting from his fame, he with a près [Death at first hand].

The memory of the Second orld War, its presence today and the debates that surround the event surely contributed to a certain fading of the memorial figure of "moral witness" of the Great ical protestation could not preical protestation could not preche the trigered. Even wo, the paifs trisgered. Even worse, the pacifist discours in the 1920 by former solder the understanding and correct apprehension of the nature of the Nazi threat. Whereas historian progressively grew interested in their testimonial writings as sources, the former 14-18 soldiers became ambivant figures as the became anbivalent figures as the combattant Dumoulin by Colucien cestich testify by presenting the poilus as sile of historians, the men at war 列 cugetions but more tham preocs individuls carth as individuals caught in the mas

From the beginning of the histor, the relationship between her evolu just as the respective ther evolved just as the respective place the passing of "latives lus" The passing of the "last poijevo of European history. On an jevo of European history. On an of writing history had established hemselves thus hus estabished themselves, thus allowing a more testimon exploitation of the mentalities was followe hy a mentalities was followed by a cultural history founded on the study of micro-history or Think also

(20) Norton Cru, Jean, Témoins, op. cit.
557-S59.

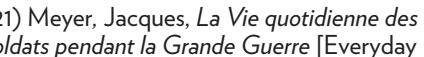
Ife of the soldieirs during the Great Warl, Paris tidienne des civils en France pendantla Grande Guerre [Everyday life of the civilians in France

(22) Winter, Jay, 'Le témoin moral et les deux two world wars]. Revue europénen d'thistaire sociale 8, 2003, 99-117. On the moral and social de Témonion of testimonies, see Dulong, Renaud de lattestation personnelle [The eye witness. Social conditions of personal testimony], Paris
EHESS 
$\ldots$ critique using the new tools of the Linguistic Turn or of the study of e memories"

The new identical editions of Témoins by Jean Norton Cru in in 2006 , and also of his section (témo 089 and 1997, revel this retro of testimonies at the cetre of the writing of histre centre of the writing of history. They are cations of "new" testimonies. In

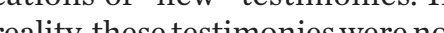
"aitly these testinon" wo . sus were dying -, these ings of soldiers, that had remained gs of soldiers, that had renained The This wave of unpublished text This wave of unpublished texts s hardly likely to diming a hould (s) cone incredible troves have been the torians, publishers, the public, has to testim ins of non-soldis, namely of occupied journals.

\section{THE DEAD CAPTURE}

\section{THE LIVING}

Testimonies became, from that point, central to the writing of history and to such an extent that elating to the history of the poits relating to the history of the poilus to them ${ }^{23}$ not to say excluively. to them, not to say exclusively. Cull beyou the histor Comic books, films, heavily Comic books, films, heavily draw costimis them, namely sue inspiredfrom then, namely or the "primary group". oldier testimonies, projects less scrupulous o ahistoricallevelhaveexploited the correst for the ion of the poilu from hero to victhe Taros de poilus which was first published in 1998 and which to this day, with more than thre million, with nore remains by farthe most widelysold remin despite the questione Great d the the quality or the collection of letters and of shitent testinonies, at times wither Audoin-Rou made. Stephane Audoin-Rouzeau and Annette ive use in year 2000. Leon sive use in year 2000. Leonard Shith anongstothers, agreed with precisely the and of testized form of proof in astinonies as a form of proof in argumentation, acorpus of testimonies to say one thing and its opposite. Part of one thing and its opposite. Part of

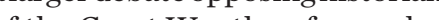
the place of witnesses and on the . work by Jean Norton Cru. Some historians, like Reny Cazals and Jenters Jean Norton Crus position and his the good and the bad witnesses, e good and the bad witnesses, ionary of witnesses published on the iny or witnesses published on plest plonted with now acons We are now at a time when

We are now at a time when the vo of the poilus is sought after and heard as never before, when dier testimonies, are central. It social and historiographic uses continue to cause a stir. But as we observe, we did not pass in linear manner from a writing of history by witnesses to a writing day, work witten by witn this and other soldier witers, posthand ously, soldin witers, posthumously, remain privileged ways of books often sell much better tha those by historians. Mnemosye has not yet defini hen

Nicolas Beaupré Clermont-Ferrand Member of the IUF iversitaire de France) and of the International Research Center of the Historia de la Grande Guerre

(23) See for example : Rousseau, Frédéric, La Guerre censuree : : une histoire des combattants
europeens de 14-18. [1999. The censod A history of the European combatants of the First World War], Paris: Seuil, 2003 and Cazals, Remy \& Andre Loez, 14-18, Wve et mourir
dans les tranchées [2008: Living and dying in dans les tranchées [2008; Living and dying in
the trenches], Paris: Tallandier, 2012. (24) Guéno, Jean-Pierre \& Yves Laplume (eds.), Paroles de
Paris: Librio, 1998 .

(25) Audoin-Rouzeau, Stéphane, 'La Grande Guerre, le deuil interminable' [The Great War,
the interminable work of mourning], Le Débat,

(26) Cazals, Rémy \& Frédéric Rousseau, 14-18, le crir une géneration [The First World War,
the scream of a generation], Toulouse: Privat. (27) See hittp:///www.crid1418.org/temoins/
directed by Rémy Cazals. For the paper version, see Cazals, Rémy, 500 Témoins de Grande Guerre $[500$ Witnesses of the Great Warl, Portet-sur-Garonne \& Moyenmoutier, 